\title{
PENGARUH MINAT DAN LINGKUNGAN KELUARGA TERHADAP KEPUTUSAN WANITA MUSLIM BERWIRAUSAHA
}

\author{
Nurudin \\ Universitas Islam Negeri Walisongo Semarang \\ e-mail: nurudin@walisongo.ac.id
}

\begin{abstract}
Abstrak
Entrepreneurship is the creative and innovative ability that is used as the basis, the tips and resources to find opportunities for success. Currently, many women are moved to create a variety of businesses that can be used as a foundation of life. Entrepreneurship is based on interest and family environment. Interest is the source of motivation that encourages a person to do the dream. Furthermore, the business experience of the family will provide an indirect experience to a person to have an entrepreneurial interest. The purpose of this study is to determine the influence of family interest and environment on the decision of Muslim women entrepreneurship. The population in this study is all Muslim women who entrepreneurship in the Village Sukodono Bonang District Demak District with a total sample of 30 respondents. Analytical techniques in this study using multiple linear regression analysis techniques. The results showed that the interest $(\mathrm{X} 1)$ has a significant effect on the decision of Muslim women entrepreneurship with $p$ value (sig) of 0.048 below 0.05 . Similarly, the family environment variable $(X 2)$ has a significant influence on the decision of Muslim women entrepreneurship, this is indicated by $\mathrm{p}$ value (sig) of 0.004 below 0.05 .
\end{abstract}

Kewirausahaan adalah kemampuan kreatif dan inovatif yang dijadikan dasar, kiat dan sumber daya untuk mencari peluang menuju sukses. Saat ini, wanita pun banyak yang tergerak untuk membuat berbagai macam usaha yang dapat dijadikan tumpuan hidup. Kewirausahaan dilatar belakangi oleh faktor minat dan lingkungan keluarga. Minat merupakan sumber motivasi yang mendorong seseorang untuk melakukan hal yang diimpikan. Selanjutnya, pengalaman usaha dari keluarga akan memberikan pengalaman secara tidak langsung kepada seseorang untuk memiliki minat berwirausaha. Tujuan penelitian ini adalah untuk mengetahui pengaruh minat dan lingkungan keluarga terhadap keputusan wanita muslim berwirausaha. Populasi dalam penelitian ini adalah seluruh wanita muslim yang berwirausaha di Desa Sukodono Ke- 
camatan Bonang Kabupaten Demak dengan jumlah sampel sebanyak 30 responden. Teknik analisa dalam penelitian ini menggunakan teknik analisa regresi linier berganda. Hasil penelitian menunjukan bahwa Minat (X1) berpengaruh signifikan terhadap keputusan wanita muslim berwirausaha dengan dengan $p$ value (sig) sebesar 0,048 di bawah 0,05. Begitu juga variabel lingkungan keluarga (X2) memiliki pengaruh signifikan terhadap keputusan wanita muslim berwirausaha, hal ini ditunjukkan dengan $p$ value (sig) sebesar 0,004 di bawah 0,05.

Kata Kunci: keputusan wanita muslim berwirausaha; lingkungan keluarga; minat

\section{A. Pendahuluan}

Semakin sulitnya mencari pekerjaan di Indonesia, menuntut seluruh masyarakat untuk tidak mengandalkan pekerjaan dari orang lain, namun menciptakan lapangan pekerjaan sendiri sehingga dapat menyerap tenaga kerja yang ada. Dengan menciptakan lapangan kerja ini, dapat meningkatkan roda perekonomian dan akhirnya dapat menurunkan tingkat pengangguran di Indonesia. Dalam hal ini, maka usaha kecil dapat dijadikan alternatif bagi masyarakat untuk dapat dijadikan pilihan menciptakan lapangan pekerjaan yang baru, karena banyak terbukti perusahaan-perusahaan skala kecil ternyata mampu bertahan dari krisis global yang pernah melanda Indonesia.

Berkembangnya barang dan jasa yang dibutuhkan oleh manusia, tidak mungkin tanpa adanya peran dari entrepreneur (wirausaha). Hal ini menunjukkan bahwa peranan wirausahawan atau masyarakat sangat penting dan strategis dalam memicu pertumbuhan dan pembangunan ekonomi suatu negara. ${ }^{1}$

Majunya perekonomian Indonesia saat ini dalam bidang wirausaha tidak hanya didominasi oleh para lelaki. Dewasa ini, wanita pun banyak yang tergerak untuk membuat berbagai macam usaha yang dapat dijadikan tumpuan hidupnya kelak atau sebagai pekerjaan sampingan untuk membantu membiayai kehidupan keluarganya. Dahulu hampir dalam segala hal perempuan ditempatkan sebagai subordinat atau pelengkap sedangkan laki-laki adalah superior atau orang yang paling di utamakan. Wanita banyak dianggap sebagai makhluk lemah yang tidak bisa melakukan sesuatu. ${ }^{2}$

${ }^{1}$ Eman Suherman, Design Pembelajaan Kewirausahaan (Bandung: Alfabeta, 2008), h. 3.

2Torado, Michael, Pembangunan Ekonomi, Jilid I (Jakarta: Bumi Aksara, 2000), h. 170. 
Wanita merupakan sumber daya yang seringkali tidak diberdayakan dalam upaya meningkatkan kesejahteraan masyarakat. Sehingga banyak potensi wanita yang terabaikan, karena kesalahan paradigma mengenai peran wanita dalam perekonomian. Padahal potensi wanita dalam meningkatkan roda perekonomian sangat besar. Dalam Islam bekerja itu sendiri diwajibkan kepada seluruh umat bagi yang mampu, tidak dikhususkan kepada laki-laki saja, sebagaimana dalam firman Allah:

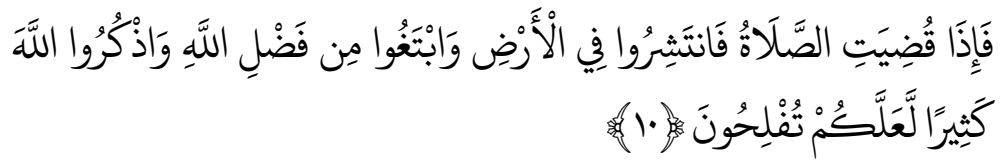

"Apabila telah ditunaikan shalat, Maka bertebaranlah kamu di muka bumi; dan carilah karunia Allah dan ingatlah Allah banyak-banyak supaya kamu beruntung."(QS. al-Jumu'ah: 10)

Seorang Muslimah berkewajiban mendukung keluarganya dalam mencari rezeki, seperti yang dicontohkan oleh Siti Khadijah istri Rasulullah SAW. Beliau merupakan suri teladan sempurna bagi seluruh perempuan di dunia. Satu hal menarik yang sering menjadi sorotan dari sosok Siti Khadijah, yaitu bahwa ia adalah seorang business woman sukses pertama di Arab pada masa itu dengan kekayaan melimpah ruah, serta perniagaan di mana-mana. ${ }^{3}$

Desa Sukodono terletak di Kecamatan Bonang Kabupaten Demak yang penduduknya 100\% Muslim dengan jumlah penduduk menurut jenis kelamin sebesar 3.072 orang terdiri dari laki-laki sebesar 1.509 orang dan wanita sebesar 1.563 orang dengan sex ratio sebesar $96,55 \%$, sedangkan jumlah wanita usia $15-$ 49 tahun sebesar 857 orang. Dengan jumlah penduduk yang berjualan atau berwirausaha sebesar 76 orang, 43 orang diantaranya dimiliki oleh wanita muslim. ${ }^{4}$

Wanita biasanya memulai usahanya didukung oleh teman-teman dekat, suami, keluarga, kelompok profesional, asosiasi pedagang dan mereka yang banyak bergerak di bidang jasa, ritel, hubungan masyarakat dan jasa pendidikan. ${ }^{5}$ Menurut HC. Witherington, minat adalah kecenderungan untuk memperhati-

\footnotetext{
${ }^{3}$ Ichwan Ziyad, "Siti Khadijah, Business Women Paling Terkenal di Dunia," dalam http://www.sekolahumarusman.com diakses pada 27 Oktober 2017.

4Badan Pusat Statistik, Kecamatan Bonang Dalam Angka 2017, 2017.

${ }^{5}$ Umar Husein, Riset dan Perilaku Pemasaran (Jakarta: Gramedia, 2000), h. 16.
} 
kan dan menyukai beberapa hal atau kegiatan, khususnya terhadap hal tertentu. Kegiatan yang diminati seseorang harus diperhatikan terus menerus yang disertai dengan rasa senang, sehingga diperoleh kepuasan. Lebih lanjut lagi, minat berwirausaha tidak dibawa sejak lahir tapi tumbuh dan berkembang sesuai dengan faktor-faktor yang mempengaruhi. ${ }^{6}$

Hurlock menyatakan bahwa minat merupakan sumber motivasi yang mendorong seseorang untuk melakukan hal yang diimpikan, terutama yang menguntungkan dan mendatangkan kepuasan. Guilford dalam Walgito mengemukakan bahwa minat adalah kecenderungan untuk memperhatikan dan mencari objek tertentu, perhatian terhadap objek cenderung mempengaruhi perilaku individu dalam kegiatan. ${ }^{7}$ Dalam penelitian ini minat yang dimaksudkan adalah kecenderungan yang tinggi dari seseorang untuk melakukan aktivitas tertentu yang disukai, didasari bakat yang dimiliki, pengalaman dan pada akhirnya mendorong seseorang untuk mengambil keputusan berwirausaha.

Dalam penelitian terdahulu Paulus Patria ${ }^{8}$ menemukan bahwa dari 95\% wirausahawan yang diteliti mempunyai orang tua atau ayah yang relatif dekat dengan dunia kewirausahaan. Cut Eriska Ananda Patimah mengemukakan bahwa pekerjaan orang tua berpengaruh signifikan terhadap intensi kewirausahaan. Kemudian Aam Bastaman seseorang yang latar belakang keluarga atau saudaranya berwirausaha memiliki tingkat intensi kewirausahaan yang lebih besar dibandingkan orang yang keluarga atau saudaranya tidak berwirausaha dimana seseorang yang keluarganya memiliki usaha telah memiliki pengalaman berwirausaha, sehingga dapat merencanakan karir berwirausaha di masa depan sebagai pilihan hidup. Hal ini menunjukkan bahwa pengalaman usaha dari keluarga akan memberikan pengalaman secara tidak langsung kepada seseorang untuk memiliki minat berwirausaha. Dewi dan Mulyatiningsih ${ }^{10}$ dalam peneliti-

${ }^{6}$ H. C. Witherington, Psikologi Pendidikan (Jakarta: Aksara Baru, 1999), h. 12..

7Zimmerer, Thomas dan Scarborough, Pengantar Kewirausahaan dan Manajemen Bisnis Kecil (Jakarta: Salemba Empat, 2004), h. 67.

8Paulus Patria Adhitama, "Faktor-faktor yang Mempengaruhi Minat Berwirausaha: Studi Kasus Mahasiswa Fakultas Ekonomi dan Bisnis Undip", 2014.

${ }^{9}$ Cut Erika Ananda Fatimah, "Faktor-faktor yang Mempengaruhi Keputusan Wanita Muslim di Wilayah Tangerang Selatan Berwirausaha", 2015.

${ }^{10}$ Anita Volintia Dewi dan Endang Mulyatiningsih, "Pengaruh Pengalaman Pendidikan Kewirausahaan dan Keterampilan Kejuruan terhadap Motivasi Berwirausaha Siswa", 2013. 
an menemukan bahwa keluarga menjadi lingkungan yang juga efektif memberikan pengalaman pendidikan kewirausahaan. Namun, hal itu akan tergantung pada latar belakang pekerjaan dan pandangan orang tua terhadap masa depan anak. Latar belakang pekerjaan orang tua yang sebagai pengusaha memang belum dapat dipastikan akan memberikan pandangan kewirausahaan kepada anaknya atau anaknya dilibatkan pada kegiatan kewirausahaan tersebut. Tetapi, secara langsung maupun tidak langsung, akan memberikan pandangan dan motivasi kepada anak untuk berwirausaha juga.

Wanita yang merupakan bagian dari anggota keluarga primer yang dituntun menjadi seseorang yang multitasking, mampu mengerjakan segala hal dalam waktu yang bersamaan, wanita dari mulai pagi sudah harus menyiapkan kebutuhan keluarga, sampai dengan urusan administrasi rumah tangga, seperti mengatur keuangan keluarga setiap bulannya. Secara tidak langsung wanita merupakan manajer bagi sebuah keluarga, yang harus mampu mengatur pendapatan keluarga seimbang dengan pengeluaran. Hal ini merupakan suatu fenomena modern saat ini, dimana seorang wanita juga dituntut untuk dapat mendukung kebutuhan rumah tangga agar terciptanya keseimbangan pendapatan dan pengeluaran dalam keluarga. Pemberdayaan wanita dalam sebuah keluarga adalah hal yang lazim saat ini agar dapat meningkatkan kesejahteraan keluarga dan juga membantu dalam perekonomi masyarakat secara umum. Terkadang wanita dipercaya dalam menjalankan dan melanjutkan bisnis keluarga atau orang tua ataupun bermitra dengan suami.

\section{B. Wirausaha dan Seluk Beluknya}

\section{Pengertian Wirausaha}

Schumpeter dalam As'ad mengemukakan bahwa wirausaha atau entrepreneur adalah seseorang yang menggerakkan perekonomian masyarakat untuk maju ke depan, mencakup mereka yang mengambil risiko, mengkoordinasi penanaman modal atau sarana produksi, yang mengenalkan fungsi faktor produksi baru atau yang mempunyai respon kreatif dan inovatif. ${ }^{11}$ Clelland dalam As'ad mendefinisikan wirausaha adalah orang yang menerapkan kemampuannya untuk mengatur, menguasai alat-alat produksi dan meng-

${ }^{11}$ Moh. As'ad, Psikologi Industri (Yogyakarta: Liberty, 2002), h. 145. 
hasilkan hasil yang berlebihan yang selanjutnya dijual atau ditukarkan dan memperoleh pendapatan dari usahanya tersebut.

Wirausaha juga dapat didefinisikan sebagai orang yang memiliki, mengelola, dan melembagakan usahanya sendiri. Faktor yang mendorong seseorang mengambil keputusan berwirausaha dapat diketahui melalui penilaian kepribadian khususnya pengalaman dan latar belakangnya. Biografi yang dimiliki seseorang bermanfaat karena dalam biografi dapat dilihat pengalaman, keterampilan, dan kompetensi untuk peningkatan kewirausahaan, pengembangan nilai-nilai kewirausahaan dan mendorong untuk mencetuskan ide-ide kewirausahaan seseorang. ${ }^{12}$

Menurut Sukardi pengertian wirausaha merujuk kepada kepribadian tertentu yaitu pribadi yang mampu berdiri di atas kekuatan sendiri. sehingga mampu mengambil keputusan untuk diri sendiri, mampu menetapkan tujuan yang ingin dicapai atas dasar pertimbangannya, sehingga seorang wirausaha ini adalah seseorang yang merdeka lahir dan batin. ${ }^{13}$ Shefsky dalam Astamoen mendefinisikan wirausaha sebagai seseorang yang memasuki dunia bisnis apa saja, tepat pada waktunya untuk membentuk atau mengubah pusat syaraf bisnis tersebut secara substansial. ${ }^{14}$

Berdasarkan pendapat para ahli, dapat disimpulkan bahwa wirausaha adalah orang yang memiliki, mengelola, melembagakan usahanya sendiri, melakukan usaha-usaha kreatif dan inovatif, mengembangkan ide dan memanage sumber daya yang ada serta memanfaatkan peluang untuk mencapai kehidupan yang lebih baik.

\section{Kewirausahaan dalam Islam}

Kewirausahaan dan Perdagangan dalam pandangan Islam merupakan aspek kehidupan yang dikelompokkan kedalam masalah mu'amalah, yaitu masalah yang berkenaan dengan hubungan yang bersifat horizontal antar manusia dan tetap akan dipertanggung-jawabkan kelak di akhirat. Manusia

\footnotetext{
${ }^{12}$ Sjanbandhy dkk, Pengembangan Kualitas SDM dari perspektif PIO (Depok: Bagian PIO fak. Psikologi UI, 2001), h. 270.

${ }^{13}$ Moh. As'ad, Psikologi Industri, h. 146.

${ }^{14}$ Astamoen Moko, Entrepreneurship dalam Perspektif Kondisi Bangsa Indonesia (Bandung: Alfabeta, 2005P), h. 25.
} 
diperintahkan untuk memakmurkan bumi dan membawanya ke arah yang lebih baik serta diperintahkan untuk berusaha mencari rizki dengan cara yang baik pula. Dalam al-Qur'an semangat kewirausahaan disebutkan dalam beberapa ayat:

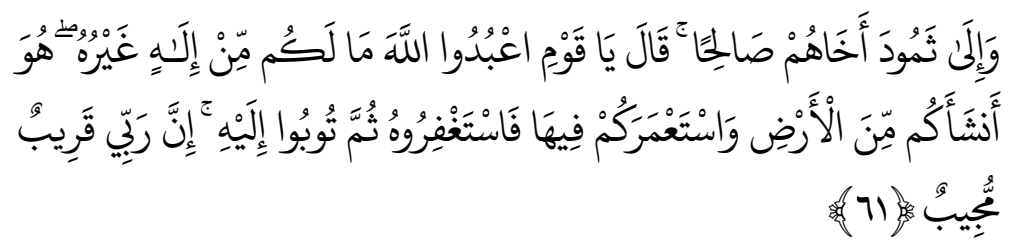

"Dan kepada Tsamud (kami utus) saudara mereka shaleh. Shaleh berkata: "Hai kaumku, sembahlah Allah, sekali-kali tidak ada bagimu Tuhan selain Dia. Dia telah menciptakan kamu dari bumi (tanah) dan menjadikan kamu pemakmurnya, karena itu mohonlah ampunanNya, kemudian bertobatlah kepada-Nya, Sesungguhnya Tuhanku Amat dekat (rahmat-Nya) lagi memperkenankan (doa hamba-Nya)." (QS. Hud [11]: 61)

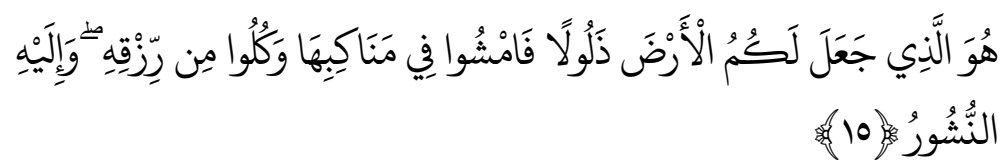

"Dialah yang menjadikan bumi itu mudah bagi kamu, Maka berjalanlah di segala penjurunya dan makanlah sebahagian dari rezkiNya. dan hanya kepada-Nya-lah kamu (kembali setelah) dibangkitkan." (QS. al-Mulk [67]: 15)

Konsep kewirausahaan telah diajarkan oleh Nabi Muhammad, jauh sebelum beliau menjadi Rasul. Rasulullah telah memulai bisnis kecil-kecilan pada usia kurang dari 12 tahun dengan cara membeli barang dari suatu pasar, kemudian menjualnya kepada orang lain untuk mendapatkan keuntungan agar dapat meringankan beban pamannya. Bersama pamannya, Rasulullah melakukan perjalanan dagang ke Syiria. Bisnis Rasulullah terus berkembang sampai kemudai Khadijah menawarkan kemitraan bisnis dengan sistem profit sharing. Selama bermitra dengan Khadijah, Rasulullah telah melakukan perjalanan ke pusat bisnis di Habasyah, Syiria dan Jorash. ${ }^{15}$ h. 27 .

${ }^{15}$ Bambang Trim, Briliant Enterpreneur Muhammad SAW (Bandung: Salamadani, 2009), 
Perjalanan bisnis Rasulullah selama bertahun-tahun memberikan hikmah tentang bagaimana unsur-unsur manajemen usaha Rasulullah. Bahkan dalam aktivitas penggembalaan kambing yang dilakukan oleh Rasulullah terdapat nilainilai luhur yang terkandung yaitu: pendidikan rohani, latihan merasakan kasih sayang kepada kaum lemah, serta kemampuan mengendalikan pekerjaan berat dan besar. Antonio mengungkapkan hikmah dari kegiatan menggembala kambing terhadap unsur-unsur manajemen adalah sebagai berikut: (1) Pathfinding (mencari); mencari padang gembalaan yang subur, (2) Directing (mengarahkan); mengarahkan kambing ke padang gembalaan yang subur, (3) Controlling (mengawasi); mengawasi kambing agar tidak tersesat atau terpisah dari kelompok, (4) Protecting (melindungi) kambing gembalaan dari hewan pemangsa dan pencuri, (5) Reflecting (perenungan) alam, manusia dan Tuhan. ${ }^{16}$

Kredibilitas dan kapabilitas Nabi Muhammad terdapat dalam empat karakter unggulnya, yaitu FAST (Fathanah, Amanah, Shiddiq dan Tabligh) ditambah faktor I, yaitu Istiqamah. Sifat Fathonah (cerdas) dalam diri Nabi Muhammad dituliskan oleh Roziah Sidik, seorang penulis asal Malaysia menyebutkan bahwa Rasulullah adalah seorang jenius dengan bukti kepakaran sebagai: 1) ahli politik; 2) ahli strategi peran; 3) ahli diplomasi; 4) ahli hubungan antar kaum; 5) ahli strategi; 6) negarawan; 7) pengambil keputusan; 8) ahli perlembagaan; 9) ahli pembangunan SDM; 10) ahli pembangunan masyarakat; 11) ahli tata keluarga; 12) ahli dakwah. ${ }^{17}$

\section{Wanita Berwirausaha}

Menurut Zimmerer, jika diperhatikan entrepreneur yang ada di masyarakat saat ini maka di jumpai berbagai macam profil wirausaha, yaitu:

\section{a. Women Entrepreneur}

Banyak wanita yang terjun ke dalam bidang bisnis. Alasan mereka menekuni bidang bisnis ini didorong oleh faktor-faktor antara lain ingin

${ }^{16}$ Syafi'i Antonio, Muhammad saw: The Super Leader Super Manager (Jakarta: ProLM, 2007), h. 17.

${ }^{17}$ Tuti Ermawati, t.th., Kewirausahaan dalam Islam, Pustaka LIPI E-Library http://www.pdii.lipi.go.id/repository/index.php/record/view/21185 diakses pada 27 Oktober 2017. 
memeperlihatkan kemampuan prestasinya, membantu ekonomi rumah tangga, frustasi dengan pekerjaan sebelumnya, dan lain sebagainya.

\section{b. Minority Entrepreneur}

Kaum minoritas terutama di negara Indonesia kurang memiliki kesempatan kerja di lapangan pemerintahan sebagaimana layaknya warga negara pada umum nya. Oleh sebab itu, mereka berusaha menekuni kegiatan bisnis dalam kegiatan sehari hari. Demikian pula para perantau dari daerah tertentu yang menjadi kelompok minoritas pada suatu daerah, mereka juga bergiat mengembangkan bisnis. Kegiatan bisnis mereka ini makin lama makin maju, dan mereka membentuk organisasi minoritas di kota-kota tertentu.

\section{c. Immigrant Entrepreneur}

Kaum pendatang yang memasuki suatu daerah biasanya sulit untuk memperoleh pekerjaan formal. Oleh sebab itu mereka lebih leluasa terjun dalam pekerjaan yang bersifat non-formal yang di mulai dari berdagang kecil kecilan sampai berkembang menjadi perdagangan tingkat menengah.

\section{d. Part-time Entrepreneur}

Memulai bisnis dalam mengisi waktu lowong atau part-time merupakn pintu gerbang untuk berkembang menjadi usaha besar. Bekerja part time tidak mengorbankan pekerjaan di bidang lain, misalnya seorang pegawai dalam sebuah kantor mencoba mengembangkan hobinya untuk berdagang atau mengembangkan suatu hobi yang menarik. Hobi ini akhirnya mendatangkan keuntungan yang lumayan. Ada kalanya orang ini beralih profesi dan berhenti menjadi pegawai dan beralih ke bisnis yang merupakan hobinya.

\section{e. Home-Based Entrepreneur}

Ada pula ibu-ibu rumah tangga yang memulai kegiatan bisnisnya dari rumah tangga, misalnya ibu-ibu yang pandai membuat kue dan aneka masakan mengirim kue-kue tersebut ke toko-toko eceran di sekitar tempatnya.

\section{f. Family Owned Entrepreneur}

Sebuah keluarga dapat membuka berbagai jenis dan cabang usaha. Mungkin saja usaha keluarga ini dimulai lebih dulu oleh bapak setelah usaha bapak maju di buka cabang baru dan dikelola oleh ibu. Kedua perusahaan ini 
maju dan membuka beberapa cabang lain mungkin jenis usahanya berbeda atau lokasinya berbeda. Masing-masing usahanya ini bisa dikembangkan atau dipimpin oleh anak anak mereka. Dalam keadaan sulitnya lapangan kerja pada saat ini maka kegiatan semacam ini perlu dikembangkan.

\section{g. Copreneurs}

Copreneurs are entrepreneurial couples who work together as co-ownners of their businesses. (Copreneurs adalah pasangan wirausaha yang bekerja bersama-sama sebagai pemilik bersama dari usaha mereka). Copreneurs ini berbeda dengan usaha keluarga yang disebut sebagai usaha Mom and Pop (Pop as "boss" and Mom as "subordinate" atau ayah sebagai pemimpin dan ibu berada di bawah kekuasaan ayah). Copreneurs dibuat dengan cara menciptakan pembagian pekerjaan yang didasarkan atas keahlian masing-masing orang. Orang orang yang ahli di bidang ini diangkat menjadi penanggungjawab divisi-divisi tertentu dari bisnis yang sudah ada. ${ }^{18}$

\section{Pengambilan Keputusan}

Pengambilan keputusan merupakan bagian penting dari aktifitas individual maupun bisnis. Pengambilan keputusan merupakan pilihan-pilihan dari dua atau lebih alternatif. Pengambilan keputusan selain mengarahkan terhadap pencapaian tujuan, juga setiap pengambilan keputusan melibatkan sejumlah resiko, jika keputusan yang diambil kurang tepat. G.R Terry menjelaskan bahwa pengambilan keputusan sebagai pilihan yang didasarkan kriteria tertentu atas dua atau lebih alternatif yang mungkin. ${ }^{19}$ Sedangkan Claude S. George Jr mengatakan pengambilan keputusan itu dikerjakan oleh kebanyakan manajer berupa suatu kesadaran, kegiatan pemikiran yang termasuk pertimbangan, penilaian, diantara sejumlah alternatif.

Keputusan untuk memilih kewirausahaan bagi wanita juga melibatkan sejumlah resiko, selain peluang yang dapat dimanfaatkan. Oleh karena itu terdapat beberapa faktor yang perlu dipertimbangkan dalam pengambilan

\footnotetext{
${ }^{18}$ Indah Purwanti, 2015."Analisis Karakteristik dan Perilaku Wanita Wirausaha", dalam http://repository.ipb.ac.id/jspui/bitstream/123456789/80860/1/H15ipu.pdf., diakses 27 Oktober 2017 2000), h. 5.

${ }^{19} \mathrm{Ibnu}$ Syamsi, , Pengambilan Keputusan dan Sistem Informasi (Jakarta: Bumi Aksara,
} 
keputusan. Dalam hal keputusan wanita untuk menjadi wirausahawan, terdapat faktor dalam diri individu sendiri (internal) dan faktor-faktor eksternal. Faktorfaktor internal antara lain: Minat, Motivasi, pemberdayaan diri. Sedangkan faktor eksternal antara lain: Lingkungan keluarga/keturunan, dukungan suami/ keluarga, sumber modal, lingkungan sosial.

\section{a. Minat}

Minat (intention) menurut Fishbein dan Icek Ajzen adalah sebuah rencana atas sepertinya seseorang akan berperilaku dari situasi tertentu dengan cara tertentu baik seseorang akan melakukannya atau tidak. Dalam kamus bahasa Indonesia, minat adalah kecenderungan hati yang tinggi terhadap sesuatu. Sementara menurut Peter dan Also minat adalah sebuah rencana untuk terlibat dalam suatu perilaku khusus guna mencapai tujuan. Sedangkan H.C. Witherington menjelaskan Minat adalah kecenderungan dalam diri individu untuk tertatik pada sesuatu objek atau menyenangi sesuatu objek. ${ }^{20}$

Minat timbul dikarenakan sebelum terlibat di dalam suatu aktivitas, mempunyai perhatian terhadap adanya perhatian, menimbulkan keinginan untuk terlibat di dalam aktivitas. Minat kemudian mulai memberikan daya tarik yang ada atau ada pengalaman yang menyenangkan dengan hal-hal tersebut. Secara skematis proses terbentuknya minat dapat digambarkan sebagai berikut:

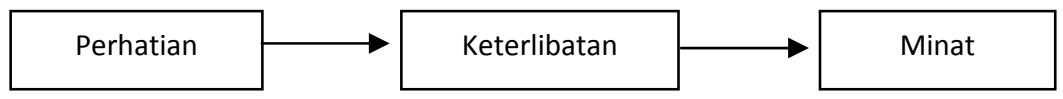

Gambar 1.

Proses Terbentuknya Minat

Jadi dapat disimpulkan bahwa minat berwirausaha adalah kecenderungan dalam diri individu untuk berwirausaha atau menyenangi kegiatan berwirausaha yang terbentuk dari perhatian dan keterlibatan dalam kegiatan wirausaha.

\section{b. Lingkungan Keluarga}

Lingkungan adalah keseluruhan fenomena (peristiwa, situasi, atau kondisi) fisik dan alam atau sosial yang memengaruhi atau dipengaruhi perkembangan individu. Keluarga terdiri dari kepala keluarga (ayah), ibu dan anak-anaknya.

${ }^{20}$ H. C. Witherington, Psikologi Pendidikan, h. 70. 
Keluarga merupakan kelompok sosial pertama dalam kehidupan manusia tempat ia belajar, menyatakan diri sebagai manusia sosial di dalam hubungan interaksi dengan kelompoknya.

Keluarga berasal dari bahasa Sansekerta, yaitu kula dan warga atau kulawarga yang berarti anggota dan kelompok kerabat. Keluarga adalah lingkungan di mana beberapa orang yang masih memiliki hubungan darah, bersatu. Keluarga inti (nuclear family) terdiri dari ayah, ibu, dan anak-anak. Keluarga merupakan tempat untuk melatih kebiasaan atau adat-istiadat dan menumbuhkan rasa susila, estetika pada anak. Keluarga tidak hanya berkewajiban dalam memelihara anak, tetapi melainkan mendidik dan membentuk sikap anak sesuai norma sosial (Wasty, 1994: 84). Dalam Islam, keluarga dikenal dengan istilah usrah, nasl, 'ali, dan nasb. Lingkungan keluarga adalah lingkungan pendidikan yang pertama, karena dalam keluarga inilah anak pertama mendapatkan pendidikan dan bimbingan dari orang tuanya atau anggota keluarganya. Di dalam keluarga inilah tempat meletakkan dasar-dasar kepribadian anak didik pada usia yang masih muda, karena pada usia ini anak akan lebih peka terhadap pengaruh dari pendidikannya (orang tua dan anggota yang lainnya).

\section{Hasil dan Analisis}

\section{Populasi dan Sampel}

Populasi dalam penelitian ini adalah seluruh wanita muslim di Desa Sukodono Kecamatan Bonang Kabupaten Demak yang berwirausaha. Berdasarkan data yang diperoleh dari data ada 76 orang yang memiliki usaha (berwirausaha) dan 43 diantaranya dimiliki oleh perempuan muslimah, sehingga populasi dalam penelitian ini adalah 78 orang.

Teknik sampling pada penelitian ini adalah probability sampling yaitu pengambilan sampel yang memberikan peluang yang sama bagi setiap unsur (anggota) populasi untuk dipilih menjadi anggota sampel. Untuk mendapatkan sampel yang menggambarkan populasi, maka dalam penelitian sampel ini digunakan formula Slovin sebagai berikut:

\section{Koefisien Determinasi}

Koefisien determinasi memiliki fungsi untuk menjelaskan sejauh mana kemampuan variabel independen (minat dan lingkungan keluarga) terhadap 
variabel dependen (keputusan wanita mulism berwirausaha) dengan melihat $\mathrm{R}$ square. Hasil koefisien determinasi dapat dilihat pada tabel di bawah ini:

Tabel 1.

Uji Koefisien Determinasi

\begin{tabular}{|c|c|c|c|c|}
\hline \multicolumn{5}{|c|}{ Model Summary ${ }^{b}$} \\
\hline Model & $\mathrm{R}$ & R Square & Adjusted R Square & $\begin{array}{l}\text { Std. Error of the } \\
\text { Estimate }\end{array}$ \\
\hline 1 & $.587^{\mathrm{a}}$ & .345 & .296 & 3.06593 \\
\hline
\end{tabular}

a. Predictors: (Constant), X2, X1

b. Dependent Variable: $Y$

Sumber : Data Primer yang diolah, 2017

Hasil analisis data pada Keputusan Wanita Mulism Berwirausaha terlihat bahwa R square sebesar 0.345 atau 34,5\%. Hal ini menunjukkan bahwa variabel independen yaitu Minat dan Lingkungan Keluarga hanya mampu menjelaskan variabel dependen sebesar 34,5\%, sisanya 65,5\% dijelaskan oleh variabel lain yang tidak ada atau tidak diperhitungkan dalam analisis penelitian.

\section{Uji Parsial (t test)}

Uji parsial ini memiliki tujuan untuk menguji atau mengkonfirmasi hipotesis secara individual antara variabel independen (minat dan lingkungan keluarga) secara parsial mempunyai pengaruh yang signifikan terhadap variabel dependen (keputusan wanita mulism berwirausaha). Hasil t test ini dijelaskan pada tabel berikut ini:

Tabel 2.

Uji Parsial (t test)

\begin{tabular}{|c|c|c|c|c|c|c|}
\hline \multicolumn{7}{|c|}{ Coefficients $^{\mathrm{a}}$} \\
\hline & \multirow{2}{*}{ Model } & \multicolumn{2}{|c|}{ Unstandardized Coefficients } & \multirow{2}{*}{$\begin{array}{c}\text { Standardized } \\
\text { Coefficients } \\
\text { Beta }\end{array}$} & \multirow[b]{2}{*}{$\mathrm{t}$} & \multirow[b]{2}{*}{ Sig. } \\
\hline & & B & Std. Error & & & \\
\hline \multirow[t]{3}{*}{1} & (Constant) & 16.128 & 3.860 & & 4.178 & .000 \\
\hline & $\mathrm{X} 1$ & -.260 & .126 & -.322 & -2.067 & .048 \\
\hline & X2 & .655 & .208 & .490 & 3.144 & .004 \\
\hline
\end{tabular}

Sumber: Data Primer yang diolah, 2017 
Dari Tabel 2 di atas, variabel minat menunjukkan nilai t hitung sebesar 2.067 dan $p$ value (sig) sebesar 0,048 yang di bawah alpha 0,05 . Artinya bahwa variabel minat berpengaruh terhadap keputusan wanita mulism berwirausaha . Begitu juga dengan variabel lingkungan keluarga menunjukkan nilai t hitung sebesar 3.144 dan $p$ value (sig) sebesar 0,004 yang di bawah alpha 0,05. Artinya bahwa lingkungan keluarga juga berpengaruh terhadap keputusan wanita mulism berwirausaha.

\section{Pengaruh Minat dan Lingkungan Keluarga terhadap Keputusan Wanita Muslim Berwirausaha}

Setelah dijabarkan mengenai hasil penyebaran angket kepada 30 responden wanita muslim yang berwirausaha di Desa Sukodono Kecamatan Bonang Kabupaten Demak untuk mengetahui pengaruh keputusan wanita muslim berwirausaha dengan variabel independen yaitu minat dan lingkungan keluarga, maka masing-masing variabel akan dijelaskan sebagai berikut:

Sebagaimana telah diuraikan diatas, bahwa minat (X1) memiliki pengaruh negatif dan signifikan terhadap keputusan wanita muslim berwirausaha sedangkan, lingkungan keluarga (X2), memiliki pengaruh positif dan signifikan terhadap keputusan wanita muslim berwirausaha. Dari hasil pengolahan statistik analisis regresi linier berganda dengan alat bantu SPSS diketahui bahwa hasil dari koefisien regresi variabel minat (X1) terhadap keputusan wanita muslim berwirausaha $(\mathrm{Y})$ sebesar $-0,260$. Untuk koefisien regresi variabel lingkungan keluarga (X2) terhadap keputusan wanita muslim berwirausaha sebesar 0,655 dengan konstanta sebesar 16,128 dan standar error sebesar 3,860.

Adapun persamaan regresi yang diperoleh dari koefisien regresi variabel minat (X1) dan lingkungan keluarga (X2) terhadap keputusan wanita muslim berwirausaha $(\mathrm{Y})$ adalah sebagai berikut:

Keputusan wanita muslim berwirausaha $=16,128-0,260$ (minat) + 0,655 (lingkungan keluarga) $+\mathrm{e}$

Berdasarkan uji regresi linier di atas, dapat ditarik kesimpulan bahwa terjadi penurunan pada variabel minat (X1) terhadap keputusan wanita muslim berwirausaha tetapi tetap mempengaruhi keputusan wanita muslim untuk berwirausaha, Penurunan minat wanita muslim ini terjadi dikarenakan tidak adanya ide atau gagasan untuk berwirausaha, ini dapat dilihat dari banyaknya 
penduduk wanita siap kerja usia 15-49 tahun sebesar 857 orang di Desa Sukodono Kecamatan Bonang Kabupaten Demak hanya ada 43 yang berwirausaha, sisanya bekerja sebagai ibu rumah tangga, buruh tani dan karyawan pabrik. Begitu juga jika terjadi peningkatan terhadap variabel lingkungan keluarga (X2) maka akan terjadi peningkatan pula terhadap keputusan wanita muslim berwirausaha. Peningkatan pada variabel lingkungan keluarga dikarenakan orang tua memiliki usaha, keluarga memberikan pendidikan dan pengalaman tentang berwirausaha. Ini sesuai dengan data yang menunjukan hanya ada 43 wanita muslim yang berwirausaha, karena dari 43 wanita muslim yang berwirausaha sebagian besar dari lingkungan keluarga yang sudah mempunyai usaha seperti usaha dagang, home industry, atau warung makan.

\section{Kesimpulan}

Dengan melihat hasil penelitian yang telah dibahas, maka dapat kita tarik kesimpulan bahwa variabel minat (X1) memiliki pengaruh signifikan terhadap keputusan wanita muslim berwirausaha, hal ini ditunjukkan $p$ value (sig) sebesar 0,048 di bawah 0,05 begitu juga dengan variabel lingkungan keluarga (X2) memiliki pengaruh signifikan terhadap keputusan wanita muslim berwirausaha, hal ini ditunjukkan dengan $p$ value (sig) sebesar 0,004 di bawah 0,05 .]

\section{Daftar Pustaka}

Adhitama, Paulus Patria, "Faktor-faktor yang Mempengaruhi Minat Berwirausaha: Studi Kasus Mahasiswa Fakultas Ekonomi dan Bisnis Undip", 2014.

Antonio, Syafi'i. Muhammad SAW: The super Leader Super Manager, Jakarta: ProLM, 2007.

Badan Pusat Statistik, Kecamatan Bonang dalam Angka 2017, 2017.

Dewi, Anita Volintia dan Endang Mulyatiningsih, "Pengaruh Pengalaman Pendidikan Kewirausahaan dan Keterampilan Kejuruan terhadap Motivasi Berwirausaha Siswa", 2013.

Ermawati, Tuti. n.d. "Kewirausahaan dalam Islam", Pustaka LIPI E-Library http://www.pdii.lipi.go.id/repository/index.php/record/view/21185 di akses pada April 2017. 
Fatimah, Cut Erika Ananda, "Faktor-faktor yang Mempengaruhi Keputusan Wanita Muslim di Wilayah Tangerang Selatan Berwirausaha", 2015.

Husein, Umar, Riset dan Perilaku Pemasaran, Jakarta: Gramedia, 2000.

Ichwan, Ziyad, Siti Khadijah, "Business Women Paling Terkenal di Dunia", dalam http://www.sekolahumarusman.com diakses pada 27 Oktober 2017

Moh, As'ad, Psikologi Industri, Yogyakarta: Liberty, 2002.

Moko, Astamoen, Entrepreneurship dalam Perspektif Kondisi Bangsa Indonesia, Bandung: Alfabeta, 2005.

Purwanti, Indah, 2015, "Analisis Karakteristik dan Perilaku Wanita Wirausaha" dalam http://repository.ipb.ac.id/jspui/bitstream/123456789/80860/1/ H15ipu.pdf., diakses 27 April 2017.

Sjanbandhy dkk, Pengembangan Kualitas SDM dari Perspektif PIO, Depok: Bagian PIO Fak. Psikologi UI, 2001.

Suherman, Eman, Design Pembelajaan Kewirausahaan, Bandung: Alfabeta, 2008.

Syamsi, Ibnu, Pengambilan Keputusan dan Sistem Informasi, Jakarta: Bumi Aksara, 2000.

Torado, Michael, Pembangunan Ekonomi, Jilid I, Jakarta: Bumi Aksara, 2000.

Trim, Bambang, Briliant Enterpreneur Muhammad SAW, Bandung: Salamadani, 2009.

Witherington, H. C., Psikologi Pendidikan, Jakarta: Aksara Baru, 1999.

Zimmerer, Thomas dan Scarborough, Pengantar Kewirausahaan dan Manajemen Bisnis Kecil, Jakarta: Salemba Empat, 2004. 